\title{
OBJECTIVATION OF THE ECOLOGICAL AND ECONOMIC LOSSES FROM SOLID DOMESTIC WASTE AT THE HEATING ENTERPRISES
}

\author{
Olga PANCHENKO, Maryna DOMASHENKO, Oleksii LYULYOV, \\ Nataliya DALEVSKA, Tetyana PIMONENKO, Natalia LETUNOVSKA \\ Sumy State University
}

\begin{abstract}
:
The aim of this research is to study theoretical and practical aspects of the ecological and economic losses from the use of solid domestic waste (SDW) as energy resources in the heat power industry of Ukraine. The methodical approaches to evaluating the ecological and economic losses caused by solid domestic waste (SDW) comprise: the developed algorithm, which evaluates the ecological and economic losses in the SDW use as fuel and energy resources in comparison with basic and project variant; the investigated morphological composition of SDW in the Ukrainian regions, on the basis of which there is proposed a matrix for further calculations of the ecological and economic loss from atmospheric pollution as a result of the energy-intensive SDW combustion at the power plants by the Ukrainian regions. The efficiency of using SDW as secondary energy resources, which essentially depends on the conventional energy resources combustion, is proved. According to the chemical and morphological composition of SDW, the average amount of harmful substances by their element constituents of SDW is determined. The economic loss from the combusting 1 ton of SDW as energy resources is estimated. Reasonability of using SDW as energy resources, based on the optimal ratio between conventional resources and energy-intensive SDW through minimizing total production costs and possible ecological and economic loss, is grounded. It is proved that while estimating the ecological and economic losses, it is necessary to consider the SDW morphological composition and regional specific features regarding the location of heat and power enterprises and organized storage landfills. It is grounded that the obtained estimates of the ecological and economic losses may be used for identifying the ecological and economic evaluation of the SDW efficiency use in the heat power industry at the regional level.
\end{abstract}

Key words: solid domestic waste (SDW); ecological and economic losses; fuel and energy resources; heat power industry

\section{INTRODUCTION}

Under modern conditions of social and economic development, the amounts of the fuel and energy resources (FER) consumption is constantly growing, which leads to the nonrenewable natural energy resources depletion and influences the energy independence of Ukraine and Poland [1]4]. Increasing of productivity efficiency leads to achieving the macroeconomic stability [5]. Macroeconomic stability is a key aspect of the innovation development [7], fostering investment climate [9], social progress [13] and country's marketing strategy [17]. At the same time, the long-term operation of resource and energy intensive industries and technologies, overconsumption and overconcentration of the production in the industrial regions justified the necessity of the alternative energy research. One of such directions may include the solid domestic waste
(SDW) use in the heat power industry, implementation of which will save natural resources (gas, coal) at the stage of their mining, transporting and consumption, and will reduce the amounts of SDW accumulation on the organized storing landfills, which will reduce the eco-destructive impact on the environment. This objectively determines the importance and necessity to carry out systematic studies regarding the improvement of ecological and economic principles of using SDW in the heat power industry according to the State Energy Strategy of Ukraine till 2030.

\section{LITERATURE REVIEW}

A great contribution to solving the environmental and economic problems regarding the management and consumption of solid waste has been made by scientists. In fact, the development does not occur without environmental burdens, and the generation of waste is one of them. Recently, 
waste has become one of the urgent topics in the scientific literature. If there are human inhabitants, waste problems will always exist. The term solid waste is used to denote hard rubbish. Household waste contributes to an absolute majority of municipal solid waste (MSW) sources to which most costs of municipal waste management are allocated. Waste management is used to decrease the negative effect of waste on human health and the environment. We can relate waste management to those activities which are engaged in recovering resources from wastes. Waste management comprises waste production prevention, reduction of the amount of waste and its negative impact on the environment.

The use and forecast of solid waste in sustainable development were studied by the authors in the papers [22]. Digestion-based waste-to-energy technology can be deployed to extract useful energy from landfills, used to reduce emissions, according to [27]. The benefits and usefulness of developing the renewable energy sources, considered together with the analysis of the most economically advantageous fields of their use, are considered by [29] and [30]. The developing countries suffer greatly from problems associated with population growth, rapid development and urbanization, providing sustainable waste management. The best and most economical method to solve these problems is to minimize the generation of waste [31] In the paper [35] the authors point out viewpoints which consider theoretical and methodical approach to the innovative regulation of the waste management sector as a global system. In addition, they investigate the mechanism of relations among countries which will promote formation and innovative development of the waste management national system through the network cooperation and state-private partnership [35]. De Feo and De Gisi emphasize that the most cost-effective method to reduce household waste includes public education and citizen encouragement to participate in the design of household recycling processes. In addition to it, this author supposes that the attempts to improve solid waste management in the developing countries focus on cost-effective waste management technologies together with source reduction, separation and recycling [36].

However, the fact that citizens participate in the source separation process strongly influences the household recycling programs' success [37].

The SWM programs, which are misunderstood by some residents, can affect the SWM participation rate in a negative way [38]. Thus, gender, age, education and the individual's income level are most commonly employed variables. The works of the abovementioned authors represent the issues regarding the reasonability of using SDW at the waste reuse in the production processes. At the same time, the analysis of these works shows that problems regarding the evaluation of the ecological and economic losses caused by SDW use in the heat power industry have not been sufficiently studied today. It confirms the urgency of the topic selected.

\section{METHODOLOGY}

The methodologic approaches to estimating the ecological and economic losses from SDW use in the Ukrainian regions have been improved on the basis of the algorithm (Figure $1)$, which outlines the stages of the ecological and economic losses evaluation at the heating enterprises by SDW combusting and storing on the landfill.

\begin{tabular}{|c|c|c|}
\hline \multicolumn{3}{|c|}{$\begin{array}{l}\text { The above algorithm can be used for any region (a territorial unit) of Ukraine, where } \\
\text { energy-intensive domestic waste is planned to be used as a fuel at the heating }\end{array}$} \\
\hline \multicolumn{3}{|c|}{ Specification of technical and technological parameters of emissions } \\
\hline $\begin{array}{l}\text { Evaluation of the emissions } \\
\text { amount from the coal and } \\
\text { gas combustion according } \\
\text { to the basic variant } \\
\text { Basic variant }\end{array}$ & \multicolumn{2}{|c|}{$\begin{array}{l}\text { Evaluation of the emissions amount from } \\
\text { the combustion of "gas-SDW" and "coal-SDW" } \\
\text { considering the seasonal factor of the SDW } \\
\text { formation and their morphological composition } \\
\text { Project variant }\end{array}$} \\
\hline \multicolumn{3}{|l|}{ Stage 2} \\
\hline $\begin{array}{l}\text { Ecological and economic } \\
\quad \text { loss from the co- } \\
\text { combustion of gas and coal } \\
\text { Basic variant }\end{array}$ & \multicolumn{2}{|c|}{$\begin{array}{l}\text { The prevented ecological and economic loss } \\
\text { from co-combustion of "gas-SDW" } \\
\text { and "coal-SDW" } \\
\text { Project variant }\end{array}$} \\
\hline \multicolumn{3}{|l|}{ Stage 3} \\
\hline \multicolumn{2}{|c|}{$\begin{array}{l}\text { Ecological and economic loss from } \\
\text { the energy-intensive SDW disposal } \\
\text { on the landfill } \\
\text { Basic variant }\end{array}$} & $\begin{array}{l}\text { The prevented ecological } \\
\text { and economic loss from the energy- } \\
\text { intensive SDW disposal on the landfill } \\
\text { Project variant }\end{array}$ \\
\hline
\end{tabular}

Fig. 1 The Algorithm for Evaluating the Ecological and conomic Loss from SDW Use as the Fuel and Energy Resources

The above algorithm can be used for any region (a territorial unit) of Ukraine, where energy-intensive domestic waste is planned to be used as fuel at the heating enterprises. The algorithm is based on the matrix calculations system (see Table 1).

Table 1

The Calculations Matrix of the Ecological and Economic Loss from the Atmospheric Pollution by Combusting the Energy-Intensive SDW at the Heating Enterprises by the Ukrainian regions

Loss by the $\mathrm{i}$ - morphological constituents of SDW $(i=1, \ldots, n)$

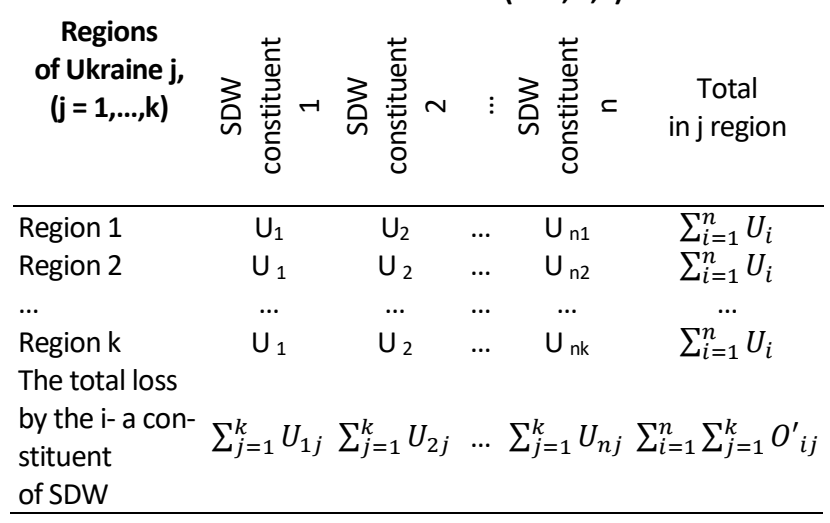

\section{RESULTS}

In order to construct the matrix, it is necessary to study the SDW morphological composition by the Ukrainian regions, which enables defining the polluting substances mass, which comes to the atmosphere after combusting 1 ton of every element of the SDW morphological composition. The 
SDW morphological composition consists of such elements as paper, carton, food waste, wood, leaves, metals, bones, skin, rubber, textile, glass, polymeric material 16 $\mathrm{mm}$. Not all these components of SDW can be used as FES at the heating enterprises. It is reasonable to use only energy-intensive waste as FES, such as paper, carton, textile, food waste. It is necessary to analyze the chemical and morphological composition of SDW by regions of Ukraine to define the amounts of energy-intensive waste. The chemical and morphological composition of SDW per 1 ton of SDW, stored on the landfills in Sumy for one year is taken as the example (Table 2). Calculations are based on the data given by the communal enterprise "Komunservice" Sumy.

Table 2

The Chemical and Morphological Composition of SDW in Sumy

\begin{tabular}{|c|c|c|c|c|c|c|}
\hline $\begin{array}{l}\text { Morphological } \\
\text { constituents } \\
\text { of SDW }\end{array}$ & 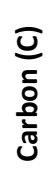 & 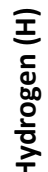 & 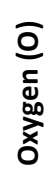 & 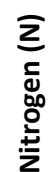 & $\begin{array}{l}\bar{n} \\
\frac{1}{3} \\
\frac{2}{5}\end{array}$ & $\stackrel{*}{\gtrless}$ \\
\hline
\end{tabular}

Paper, carton 15.0161 .97213 .8060 .2760 .11210 .75917 .871 $\begin{array}{lllllllll}\text { Food waste } & 4.004 & 0.525 & 3.681 & 0.071 & 0.030 & 2.869 & 4.765\end{array}$ $\begin{array}{llllllll}\text { Wood, leaves } & 2.567 & 0.337 & 2.360 & 0.047 & 0.019 & 1.839 & 3.055\end{array}$ $\begin{array}{llllllll}\text { Textile } & 2.002 & 0.262 & 1.840 & 0.036 & 0.015 & 1.434 & 2.382\end{array}$ $\begin{array}{llllllll}\text { Waste } 16 \mathrm{~mm} & 5.091 & 0.668 & 4.681 & 0.093 & 0.038 & 3.648 & 6.059\end{array}$ Ap* - slaggy constituent; Bp** - humidity composition

Having defined the energy-intensive composition of SDW, considering the geographical location of the Ukrainian regions, the matrix for ecological and economic loss caused by the air pollution of waste combustion by their morphological constituents, is defined. Using the information regarding the morphological composition of SDW by the Ukrainian regions, one can calculate the total ecological and economic loss from the combustion of every SDW element. It should be mentioned that the SDW storing process has various features in various Ukrainian regions, particularly in the Northern Ukraine, including Zhytomyr, Kyiv, Sumy, Chernihiv districts; the Southern Ukraine, including Odesa, Mykolaiv, Kherson districts, the Crimea with Sevastopol and Zaporizhzhia district; the Eastern Ukraine including Luhansk, Kharkiv, Donetsk districts; the Central Ukraine including Vinnytsia, Dnipropetrovsk, Kirovohrad, Poltava and Cherkasy districts; the Western Ukraine including five districts - Lviv, Ivano-Frankivsk, Ternopil, Volyn and Rivne. Uneven distribution of citizens by the administrative and territorial units forms the uneven load on the environment.

The analysis performed proves that the territories with the highest population density pollute the environment heavily with SDW (Kaufman et al. 2010). The economic loss from combusting 1 ton of SDW as energy resources in Sumy is evaluated.
Table 3

Harmful Substances Produced by Combusting

1 Ton of SDW, $\mathrm{kg}$

\begin{tabular}{lccccc}
\hline & & & \multicolumn{3}{c}{$\mathbf{1}$ Ton of SDW, $\mathbf{~ g}$} \\
\hline Paper, carton & 355.120 & $\mathbf{N}_{2} \mathbf{O}$ & $\mathbf{S O}_{2}$ & $\mathbf{C O}$ & $\mathbf{C O}_{2}$ \\
Food waste & 94.699 & 0.782 & 625.606 & 6.298 & 55002.790 \\
Wood, leaves & 60.731 & 0.501 & 38.582 & 1.679 & 14667.411 \\
Textile & 47.349 & 0.391 & 30.081 & 0.840 & 7333.705 \\
Waste $16 \mathrm{~mm}$ & 120.432 & 0.994 & 76.510 & 2.136 & 18653.120 \\
\hline
\end{tabular}

The economic loss from polluting with harmful substances resulting from the SDW combustion at the heating enterprises in the regions is calculated by the formula:

$$
Y_{j}^{a t m}=\sum Y_{i}^{a t m . j} \times m_{i},
$$

where:

$Y_{i}^{\text {atm.j }}$ is a specific ecological and economic loss, caused by the air pollution by one ton of $i$ - polluting substance $(i=1, \ldots, 5)$, included to the morphological composition of SDW in j-region, UAH/tons equivalent; $m_{i}$ is a mass of $i$ - polluting substance in the $j$-region, $t$.

In its turn, the specific loss from air pollution with emissions of the harmful substances resulting from combusting 1 ton of SDW by the morphological composition considering the regional characteristics is calculated by the formula:

$$
Y_{i}^{a t m . j}=j_{i}^{j} \times \sigma_{i}^{j} \times f_{i}^{j} \times m_{e m_{i}}^{j}
$$

where:

$j_{i}^{j}$ is a specific loss of the national economy, caused by emissions of one ton of the polluting substances into the atmosphere in $j$-region.

When the methodology was investigated by the Presidium of USSR Academy of Science in 1983, the specific loss of the national economy, caused by emissions of one ton of the polluting substances into the atmosphere, was $j_{i}^{j}=2.4 \mathrm{rub} /$ tons equivalent. Taking into consideration the indexation of this indicator in $2017 j_{i}^{j}=2.4 \mathrm{rub} /$ tons equivalent in the current period, we have: (1 karbovanetz $=1.37 \$$ in 1983), ( $\$=26.15 \mathrm{UAH}$ in 2017 . Then, the specific economic loss caused to the environment by the emissions into the atmosphere in 2017 will be calculated $2.4 \cdot 1.37 \cdot 26.15=85.98 \mathrm{UAH} /$ tons equivalent [35]; $\sigma_{i}^{j}$ is a dimensionless indicator of the relative risk regarding the atmospheric pollution in j-region; $f_{i}^{j}$ is an amendment, which considers the nature of impurities dispersion in the atmosphere in j-region; $\mathrm{m}_{\mathrm{em}}^{\mathrm{j}}$ is a mass of the above emissions formed in j-region, from the combustion of 1 ton of $\mathrm{i}$-substance. This parameter is calculated by the formula:

$$
m_{e m_{i}}^{j}=\sum A_{i k}^{j} \times m_{e m_{i k^{\prime}}}^{j}
$$

where:

$A_{i k}^{j}$ is an indicator of the relative aggressiveness of $k$-impurity of $i$-substance in $j$-region, tons equivalent/tons;

$\mathrm{m}_{\mathrm{em}}^{\mathrm{j}}$ is a mass of emissions of $k$-impurity from the combustion of one ton of $i$-polluting substance in $j$-region, tons equivalent/tons. 
The combustion of conventional fuels, gas, and coal is taken as a basic variant, and harmful emissions per 1000 $\mathrm{m}^{3}$ of gas and 1 ton of coal are determined. The ecological and economic loss is estimated by the formula (1)-(3), Table 4 .

Table 4

The Basic Evaluation of the Ecological and Economic Loss Indicators from the Combustion of Conventional Fuels

Basic variant

\begin{tabular}{|c|c|c|c|c|c|}
\hline \multicolumn{3}{|c|}{ gas (100\%) } & \multicolumn{3}{|c|}{ coal (100\%) } \\
\hline 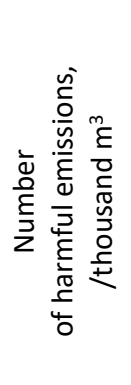 & 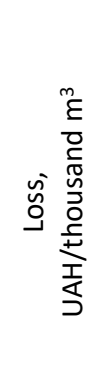 & 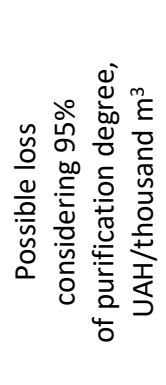 & 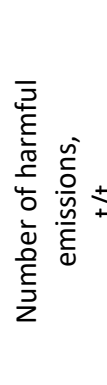 & 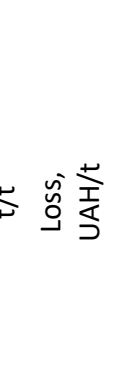 & 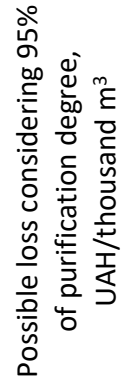 \\
\hline 42.92 & 669.45 & 60.25 & 66.38 & 1035.4 & 51.77 \\
\hline
\end{tabular}

The number of harmful emissions and ecological and economic loss are defined by analogy from the combustion of the fuel and energy resources in the ratio "gas (70\%) SDW (30\%)", "coal (80\%) - SDW (20\%). Therefore, the economic loss is found in terms of 1 thousand $\mathrm{m}^{3}$ per 1 thousand ton of fuel equivalent.

Such a difference in the ratio between "gas and SDW" and "coal and SDW" depends on the heat-generating capacity of the fuel. According to the statistic data, gas has the largest heat-generating capacity, which is $33.56 \mathrm{MJ} / \mathrm{m}^{3}$, coal $22.176 \mathrm{MJ} / \mathrm{kg}$, and the least heat can be produced from the combustion of SDW, that is $22.176 \mathrm{MJ} / \mathrm{kg}$.

Having analysed Tables 4-5, it may be concluded that the number of harmful emissions in the predicted variant is decreasing. It is caused by the fact that the combustion of coal with SDW is ecologically and economically beneficial.

Table 5

The Predicted Evaluation of the Specific Indicators Regarding the Ecological and Economic Loss from the Combustion of the Conventional Fuel and Energy-Intensive SDW

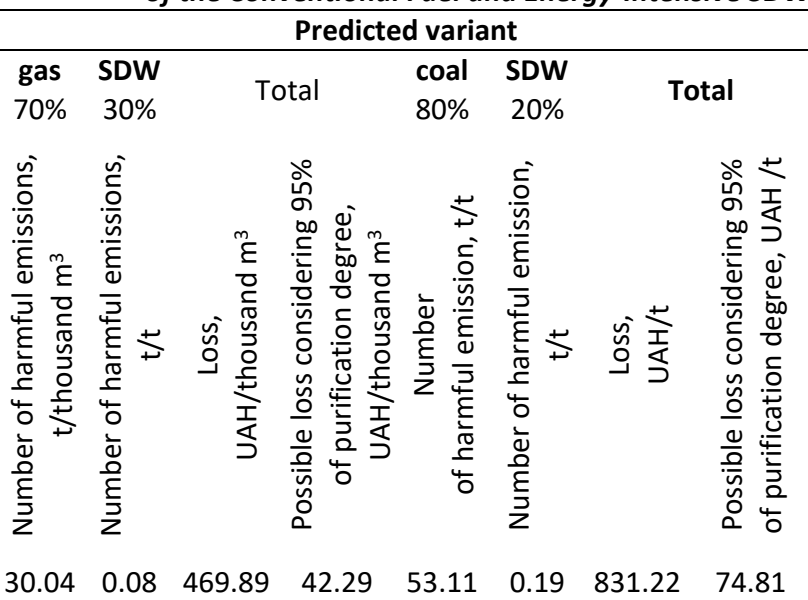

Firstly, it will enable saving funds to purchase fuel, secondly, emissions into the atmosphere will be reduced from the combustion of coal with its partial substitution by the energy-intensive SDW.

Table 6 demonstrates calculations of the ecological and economic loss at the heating enterprises from the combustion of gas and coal in the basic variant for comparison.

Table 6

The Evaluation of the Specific Indicators Regarding the Ecological and Economic Loss from the Combustion of Conventional Fuels

\begin{tabular}{lll}
\hline & Basic variant \\
\hline gas (100\%) & $\operatorname{coal}(100 \%)$
\end{tabular}

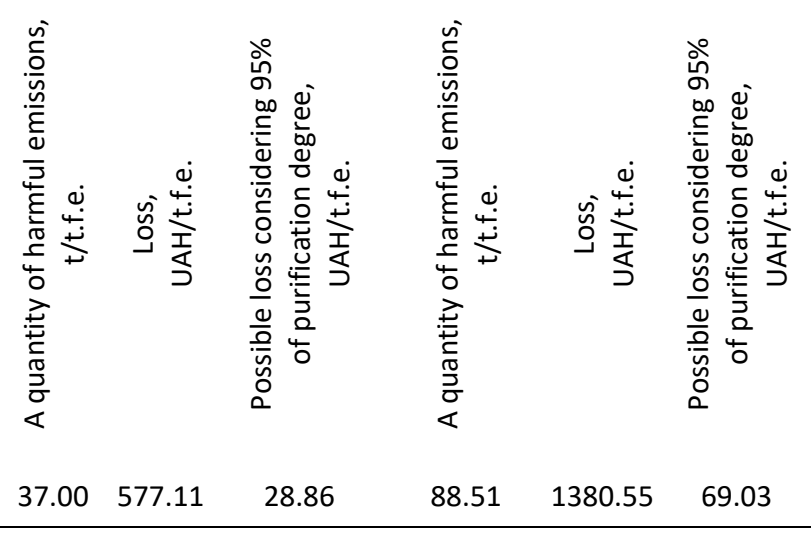

Table 7 demonstrates the ecological and economic loss from the combustion of SDW together with conventional fuel, Table 7.

Table 7

The Predicted Variant of Calculating the Ecological and Economic Loss from the Combustion of the Conventional Fuels and Energy-Intensive SDW

\begin{tabular}{llllll}
\hline \multicolumn{5}{c}{ Predicted variant } \\
\hline Gas & SDW & \multirow{2}{*}{ Total } & Coal & SDW & Total \\
$70 \%$ & $30 \%$ & & $80 \%$ & $20 \%$ &
\end{tabular}

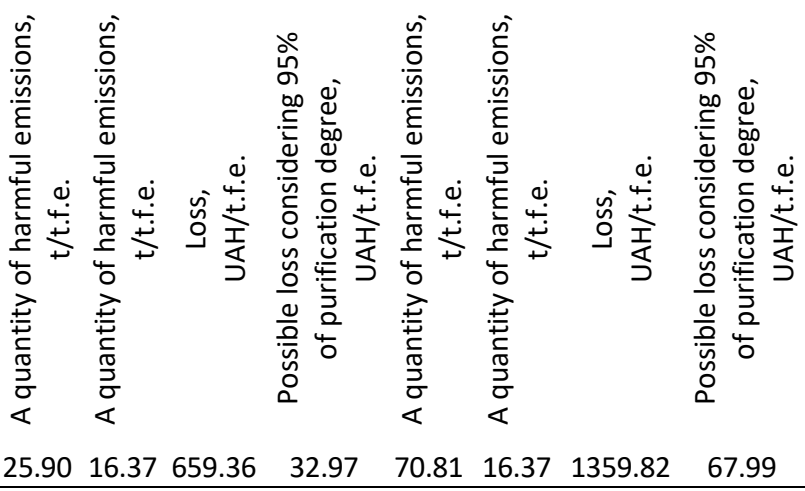

Calculations of the ecological and economic loss from the combustion of 1 ton of SDW by their morphological composition at the heating enterprises by the Ukrainian regions, is performed by the matrix, shown in Table 8 . 
Table 8

The Matrix Calculating the Specific Ecological and Economic Losses from the Combustion of 1 Ton of SDW by Element Constituents at the Heating Enterprises by the Ukrainian Regions

Morphological constituents of SDW

\begin{tabular}{|c|c|c|c|c|c|c|}
\hline $\begin{array}{l}\text { Regions } \\
\text { of } \\
\text { Ukraine } \\
\text { (j) }\end{array}$ & 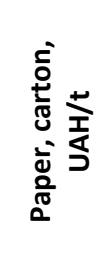 & 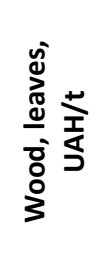 & 兽 & 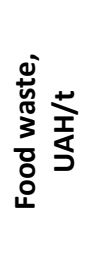 & 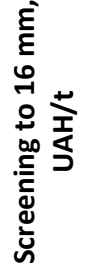 & 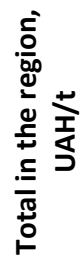 \\
\hline $\begin{array}{l}\text { North } \\
\text { (1) }\end{array}$ & 15.878 & 23.162 & 23.396 & 7.487 & 7.954 & 77.88 \\
\hline $\begin{array}{l}\text { South } \\
\text { (2) }\end{array}$ & 19.847 & 28.952 & 29.245 & 9.358 & 9.943 & 97.35 \\
\hline $\begin{array}{l}\text { East } \\
\text { (3) }\end{array}$ & 16.239 & 23.688 & 23.9274 & 7.657 & 8.135 & 79.65 \\
\hline $\begin{array}{l}\text { West } \\
\text { (4) }\end{array}$ & 18.765 & 27.373 & 27.649 & 8.848 & 9.400 & 92.04 \\
\hline $\begin{array}{c}\text { Center } \\
\text { (5) }\end{array}$ & 16.239 & 23.688 & 23.927 & 7.657 & 8.135 & 79.65 \\
\hline
\end{tabular}

\section{DISCUSSION AND CONCLUSIONS}

The performed studies enable concluding that efficiency of using solid domestic waste (SDW) as the secondary energy resources greatly depends on the combustion amount of conventional energy resources. The reasonability to use SDW as energy resources is substantiated. It is based on determining the optimal ratio between amounts of using conventional energy resources and energy-intensive SDW, based on the minimization of total production costs and possible ecological and economic loss.

It is proved that while evaluating the ecological and economic losses, there must be considered the morphological composition of SDW and regional features of the heating enterprises and landfills location. The performed complex of calculations shows that the estimated ecological and economic losses from the combustion of $100 \%$ of gas and coal account for 577.11 and 1380.55 (thousand $\mathrm{UAH} / \mathrm{t}$.f.e) correspondingly. According to the project variant in case of the conventional fuel co-combustion from SDW, losses amount to: "gas - SDW" - 659.36 UAH/t.f.e, "coal - SDW" - 1359.82 UAH/t.f.e. The obtained evaluations of the ecological and economic loss can be implemented in determining the ecological and economic evaluation regarding the efficiency of using SDW in the heat power industry at the regional level.

\section{FUNDING}

This research was funded by the grants from the Ministry of Education and Science of Ukraine (0120U102001) and National Research Foundation of Ukraine ("Quadrocentric recrusive model of Ukrainian unshadow economy to increase its macroeconomic stability" 01200104798 and
"Stochastic modelling of road map for harmonizing national and European standards for energy market regulation in the transition to a circular and carbon-free economy", 0120U104807).

\section{REFERENCES}

[1] K. Pajak, O. Kvilinskyi, O. Fasiecka, and R. Miśkiewicz. “Energy Security in Regional Policy in Wielkopolska Region of Poland." Economics and Environment, vol. 2(61), pp. 122138, 2017. https://www.ekonomiaisrodowisko.pl/uploads/eis\%2061/11_pajak.pdf

[2] A. Kuzior, A. Kwilinski, and V. Tkachenko. "Sustainable Development of Organizations Based on the Combinatorial Model of Artificial Intelligence." Entrepreneurship and Sustainability Issues, vol. 7(2), pp. 1353-76, 2019. https://DOI.org/10.9770/ jesi.2019.7.2(39).

[3] T. Vasylieva, V. Kasyanenko. "Integral assessment of innovation potential of ukraine's national economy: A scientific methodical approach and practical calculations." Actual Problems of Economics, vol. 144(6), pp. 50-59, 2013.

[4] A. Bonamigo and M. Dayse. "Value Co-creation and Leadership: An Analysis Based on the Business Ecosystem Concept." Business Ethics and Leadership, vol. 3(4), pp. 66-73, 2019. http://DOI.org/10.21272/bel.3(4). 2019.

[5] O. Rodina, T. Savchenko, N. Basiurkina, and A. Kwilinski. "Improvement of the Assessment Methods of Product Competitiveness of the Specialized Poultry Enterprises." Management Theory and Studies for Rural Business and Infrastructure Development, vol. 41, no. 1, pp. 43-61, 2019. https://DOI.org/10.15544/mts.2019.05.

[6] H. Dzwigol, M. Dzwigol-Barosz, R. Miskiewicz, and A. Kwilinski. "Manager Competency Assessment Model in the Conditions of Industry 4.0." Entrepreneurship and Sustainability, vol. 7, no. 4, pp. 2630-44. 2020. https://doi.org/10.9770/jesi.2020.7.4(5).

[7] I. Kendiukhov, M. Tvaronaviciene. "Managing Innovations in Sustainable Economic Growth." Marketing and Management of Innovations, vol. 3, pp. 33-42, 2017. http://DOI.org/10.21272/mmi.2017.3-03.

[8] A. Kwilinski. "Mechanism of Modernization of Industrial Sphere of Industrial Enterprise in Accordance with Requirements of the Information Economy." Marketing and Management of Innovations, vol. 4, pp. 116-28, 2018.

[9] S. Leonov, S. Frolov, V. Plastun. "Potential of institutional investors and stock market development as an alternative to households' savings allocation in banks." Economic Annals-XXI, vol. 11-12, pp. 65-68, 2014.

[10] A. Vysochyna, O. Kryklii, M. Minchenko, A. Aliyeva, K. Demchuk, K. "Country Innovative Development: Impact of Shadow Economy." Marketing and Management of Innovations, vol. 4, pp. 41-49, 2020. http://DOI.org/10.21272/mmi.2020.4-03

[11] Y. Bilan, I. Tiutiunyk, S. Lyeonov, and T. Vasylieva. "Shadow economy and economic development: A panel cointegration and causality analysis." International Journal of Economic Policy in Emerging Economies, vol. 13(2), pp. 173193, 2020. DOI:10.1504/IJEPEE.2020.107929

[12] A. Buriak, S. Lyeonov, T. Vasylieva. "Systemically important domestic banks: An indicator-based measurement approach for the ukrainian banking system." Prague Economic Papers, vol. 24(6), pp. 715-728, 2015. DOI:10.18267/j.pep.531 
[13] A. Kuzior. "Polskie i niemieckie doświadczenia w projektowaniu i wdrażaniu zrównoważonego rozwoju [ Polish and German Experiences in Planning and Implementation of Sustainable Development ]." Problemy Ekorozwoju Problems Of Sustainable Development vol. 5(1), pp. 81-89, 2010.

[14] L. Hrytsenko, M. Petrushenko, K. Daher. "The Necessity of Socio-Ecological Modification of Two-Tier Economic Model of Secondary Resources Management in Ukraine." SocioEconomic Challenges, vol. 1(1), pp. 68-76, 2017. http://DOI.org/10.21272/sec.2017.1-08.

[15] T. Vasilieva, S. Lieonov, I. Makarenko, and N. Sirkovska. "Sustainability Information Disclosure as an Instrument of Marketing Communication with Stakeholders: Markets, Social and Economic Aspects." Marketing and Management of Innovations, vol. 4, pp. 350-357, 2017. https://DOI.org/10.21272/mmi.2017.4-31.

[16] J. Tsalikis, B. Seaton. "Corporate Social Responsibility: A Cross-National Study of the Treatment of Consumers and Employees." Business Ethics and Leadership, vol. 4(2), pp. 6-15, 2020. https://DOI.org/10.21272/bel.4(2).6-15.2020.

[17] A. Kuzior, and A. Lobanova. "Tools of Information and Communication Technologies in Ecological Marketing under Conditions of Sustainable Development in Industrial Regions (Through Examples of Poland and Ukraine)." Journal of Risk and Financial Management, vol. 13(10), p. 238. 2020. https://DOI.org/10.3390/jrfm13100238

[18] A. Kwilinski, K. Pajak, O. Halachenko, S. Vasylchak, Y. Pushak, and P. Kuzior. "Marketing Tools for Improving Enterprise Performance in the Context of Social and Economic Security of the State: Innovative Approaches to Assessment." Marketing and Management of Innovations, vol. 4, pp. 172-181, 2019. http://DOI.org/10.21272/ mmi.2019.4-14

[19] L. Lipkova, and D. Braga. "Measuring commercialization success of innovations in the EU." Marketing and Management of Innovations, vol. 4, pp. 15-30, 2016.

[20] A. Bondarenko, L. Zakharkina, L. Syhyda, L. Saher. "The economic and marketing attractiveness of countries: Measurement and positioning in terms of economic security. "International Journal of Sustainable Development and Planning, vol. 15(4), pp. 439-449, 2020. DOI:10.18280/ijsdp.150404

[21] A. Rosokhata, O. Rybina, A. Derykolenko, V. Makerska. "Improving the classification of digital marketing tools for the industrial goods promotion in the globalization context." Research in World Economy, vol. 11(4), pp. 42-52, 2020. DOI:10.5430/rwe.v11n4p42

[22] B. Batinić, S, Vukmirović, G. Vujić, N. Stanisavljević, D. Ubavin, and G. Vukmirović. "Using ANN Model to Determine Future Waste Characteristics in Order to Achieve Specific Waste Management Targets-Case Study of Serbia." Journal of Scientific \& Industrial Research, vol. 70, pp. 13-18, 2011.

[23] K.J. Sudhir, K.V. Subbaiah, and P.V.V P. Rao. "Prediction of Municipal Solid Waste with RBF Net Work - A Case Study of Eluru, A.P., India." International Journal of Innovation, Management and Technology, vol. 2.3, pp. 238-243, 2011.

[24] F. Sylwester, P.A. Gauden, A. Patrykiejew, G. Szymański, R. Miśkiewicz, and P. Kowalczyk. "In Silico Study on the Effects of Carbonyl Groups on Chemical Equilibrium of Reactions with a Polar Product Occurring under Confinement in Pores of Activated Carbons." Chemical Engineering Communications, pp. 1-12, 2019. https://DOI.org/10.1080/ 00986445.2019 .1700115 .
[25] J. Cherian, and J. Jolly. "Management Models of Municipal Solid Waste: A Review Focusing on Socio Economic Factors." International Journal of Economics and Finance, vol. 4, no. 10, 2012. https://DOI.org/10.5539/ijef.v4n10p131.

[26] H. Dkhili. "Environmental Performance and Institutions Quality: Evidence from Developed and Developing Countries." Marketing and Management of Innovations, vol. 3, pp. 333-44, 2018. https://DOI.org/10.21272/mmi.2018.330.

[27] S. Kaufman, K. Nikhil, and N.J. Themelis. "A Screening Life Cycle Metric to Benchmark the Environmental Sustainability of Waste Management Systems." Environmental Science \& Technology, vol. 44 (15), pp. 5949-55, 2010. https://DOI.org/10.1021/es100505u.

[28] E. Spremberg, V. Tykhenko, and L. Lopa. "Public-Private Partnership in the Implementation of National Environmental Projects." SocioEconomic Challenges, vol. 1(4), pp. 73-81, 2017. DOI: $10.21272 \mathrm{sec} .1(4) .73-81.2017$

[29] T. Kurbatova. "State and Economic Prospects of Developing Potential of Non-Renewable and Renewable Energy Resources in Ukraine." Renewable and Sustainable Energy Reviews, vol. 52, pp. 217-26, 2015. DOI:10.1016/ j.rser.2015.07.093.

[30] E.A. Adil, R. Boutti, F. Rodhain. "Sustainable Finance at the Time of Institutions: Performativity through the Lens of Responsible Management in Morocco." Financial Markets, Institutions and Risks, vol. 4(2), pp. 52-64. 2020. https://DOI.org/10.21272/fmir.4(2).52-64.2020.

[31] F. Trisia, and C. Tucker. "Action Research and Residential Waste Minimisation in Palmerston North, New Zealand." Resources, Conservation and Recycling, vol. 91, pp. 11-26, 2014.

[32] C. Bazyli, A. Matuszczak, and R. Miśkiewicz. "Public Goods Versus the Farm Price-Cost Squeeze: Shaping the Sustainability of the EU's Common Agricultural Policy." Technological and Economic Development of Economy, vol. 25, no. 1, pp. 82-101, 2019. https://DOI.org/10.3846/ tede.2019.7449.

[33] H. Luc, L. Melnyk, O. Matsenko, O. Chygryn, and C. Chamorro Gonzales. "Transport Economics and Sustainable Development in Ukraine." Marketing and Management of Innovations, no. 3, pp. 272-84, 2019. https://DOI.org/10.21272/mmi.2019.3-21.

[34] K.M. Atif, and A. Kishwar. "Natural Resource Rent and Financial Development Nexuses in Bangladesh: The Role of Institutional Quality." Financial Markets, Institutions and Risks, vol. 4(2), pp. 108-114, 2020. https://DOI.org/10.21272/fmir.4(2).108-114.2020.

[35] H-Ch. Brauweiler, V. Shkola, and O. Markova. "Economic and Legal Mechanisms of Waste Management in Ukraine." Marketing and Management of Innovations, vol. 2, pp. 359-68. 2017. https://DOI.org/10.21272/mmi.2017.2-33.

[36] G. De Feo, and G. Sabino De. "Public Opinion and Awareness towards MSW and Separate Collection Programmes: A Sociological Procedure for Selecting Areas and Citizens with a Low Level of Knowledge." Waste Management, vol. 30.6, pp. 958-976, 2010.

[37] K.M. Keramitsoglou, and K.P. Tsagarakis. "Public Participation in Designing a Recycling Scheme towards Maximum Public Acceptance." Resources, Conservation and Recycling, vol. 70, pp. 55-67, 2013. https://DOI.org/10.1016/ j.resconrec.2012.09.015

[38] M. Purcell, and W.L. Magette. "Attitudes and Behaviour towards Waste Management in the Dublin, Ireland Region." Waste Management, vol. 30, pp. 1997-2006, 2010. DOI:10.1016/j.wasman.2010.02.021. 
[39] S. Joshi, P. Bhargava "Waste Management Integration with Green Quality Function Deployment (G-QFD) for Healthcare Centre", Production Engineering Archives, Vol. 22, pp. 45-49. 2019 DOI: https://DOI.org/10.30657/ pea.2019.22.09

\section{Olga Panchenko}

ORCID ID: 0000-0002-1859-1385

Sumy State University

Department of Management

Academic and Research Institute of Business,

Economics and Management

Rymskogo-Korsakova st., 2, 40007 Sumy, Ukraine

e-mail: o.panchenko@management.sumdu.edu.ua

\section{Maryna Domashenko}

ORCID ID: 0000-0002-6987-8992

Sumy State University

Department of International Economic Relations

Academic and Research Institute of Business,

Economics and Management

Rymskogo-Korsakova st., 2, 40007 Sumy, Ukraine

e-mail:687737fem@gmail.com

\section{Oleksii Lyulyov}

ORCID ID: 0000-0002-4865-7306

Sumy State University

Department of Marketing

Academic and Research Institute of Business,

Economics and Management

Rymskogo-Korsakova st., 2, 40007 Sumy, Ukraine

e-mail: alex_lyulev@econ.sumdu.edu.ua

\section{Nataliya Dalevska}

ORCID ID: 0000-0002-0074-497X

Donetsk National Technical University

Department of Economics of Enterprises

Pokrovsk, 85300, Ukraine

e-mail: dalevskanm@gmail.com

Tetyana Pimonenko (Corresponding Autor's)

ORCID ID: 0000-0001-6442-3684

Sumy State University

Department of Marketing

Academic and Research Institute of Business,

Economics and Management

Rymskogo-Korsakova st., 2, 40007 Sumy, Ukraine

e-mail: tetyana_pimonenko@econ.sumdu.edu.ua

\section{Natalia Letunovska}

ORCID ID: 0000-0001-8207-9178

Sumy State University

Department of Marketing

Academic and Research Institute of Business,

Economics and Management

Rymskogo-Korsakova st., 2, 40007 Sumy, Ukraine

e-mail: n.letunovska@kmm.sumdu.edu.ua
[40] A. Kluczek. Multi-criteria decision analysis for simplified evaluation of clean energy technologies, Production Engineering Archives, Vol. 23, pp. 3-11. 2019 DOI: https://doi.org/10.30657/pea.2019.23.01 